\title{
Availability of financial support for the young generation in commercial farming: legal incentives
}

\author{
By Magdalena Sylister*
}

\section{A. ABSTRACT}

This paper critically examines the access to financial resources by the Tanzanian young men and women for commercial farming purposes. The main aim of this endeavour is to recommend the type of effective legal incentives that are needed in order to boost access to those resources by that said population group. The thesis of this work is that effective youth-centred legal incentives will simplify availability of financial support to the young generation hence increasing the number of young people engaging in commercial farming in Tanzania.

The paper begins with highlighting the context of young people's engagement in commercial farming in Tanzania, followed by the Tanzania's vision on agriculture. Thereafter, the paper looks at an overview of the efforts made to attract the young generation into agribusiness. That part is followed by an examination of factors that prevent young people from fully engaging in commercial farming, with an emphasis on the question of availability of financial support. At that point, the paper expounds how lack of funds is a major obstacle that stands between the Tanzanian young generation and their dream of economic sustainability through commercial agriculture. Finally, the paper discusses the types of legal incentives that are needed so as to make financial support for agribusiness easily accessible to the young generation.

\section{B. INTRODUCTION}

Commercial farming is one of the highly potential economic activities that could greatly benefit a large portion of the Tanzanian young generation and lead to sustainable development. Tanzania has adequate arable land for both crop cultivation and animal husbandry, suitable climatic conditions, a wide internal and external market and a number of other conducive factors. Unfortunately, despite that promising environment, the number of young people engaging in commercial agriculture in Tanzania is very small. In some occasions, even the ones who were doing some farming activities have been moving to other ventures which offer quicker gains.

* Tanzanian, Assistant Lecturer at the Saint Augustine University of Tanzania, Arusha, Tanzania; LL. M. (Distinction), University of Dar es salaam, Tanzania in association with the University of Bayreuth, Germany; LL. B. (Hons), University of Dar es salaam; Executive Director of the Foundation for Research and Assistance in Law; Advocate of the High Court and courts subordinate thereto save for primary courts, magdalenasylister@gmail.com. 
Undoubtedly, that problem is caused by a number of reasons one of the major ones being lack of financial resources for accessing land, farm inputs, equipment and other necessary requirements. A number of strategies are needed to address that problem and youthcentred legal incentives are among the much needed solutions. Those incentives are crucial because they will make commercial farming more attractive to the young generation hence increasing the number of the young people engaging in that activity.

This paper critically examines the access to financial resources by the Tanzanian young men and women with a view to recommend the type of effective legal incentives that are needed in order to boost access to those resources by that said population group. Effective youth-centred legal incentives will simplify availability of financial support to the young generation hence increasing the number of young people engaging in commercial farming in Tanzania.

\section{THE CONTEXT OF YOUTH AND COMMERCIAL FARMING IN TANZANIA}

Tanzania has one of the world's youngest population with 45 percent being under the age of 15,35 percent between the ages of $15-35$, and with a median age for the population of 17.3 years (in 2015). ${ }^{1}$ It is projected that in 2050 Tanzania's population will be one of the world's ten youngest populations. ${ }^{2}$ Furthermore, with an annual population growth rate slightly over three percent (in 2017), the population is expected to double in 23 years. ${ }^{3}$ The data means that the youth form a very large population group in Tanzania.At the same time, a majority of the Tanzanian population still resides in rural areas. ${ }^{4}$ Thus, to a large extent this is also where the population increase will take place. ${ }^{5}$

A rapidly growing population puts high pressure on Tanzania's agricultural sector to meet its domestic demands and guarantee food security. ${ }^{6}$ Potentially, the agricultural sector could absorb and employ a large share of the young population and help them form their independent livelihoods, and potentially the youth could play a key role in addressing the challenges related to domestic food demands and food security. ${ }^{7}$ Unfortunately, that does not seem to happen any time soon due to the obstacles discussed in this work.

1 Agnes Andersson Djurfeldt, Aida Cuthbert Isinika, ElibarikiMsuya and Karin Lindsjö, Youths' Participation in Agricultural Intensification in Tanzania, AIMS Agriculture and Food, volume 5, 2020, p. 682, available at https:/www.aimspress.com/article/doi/10.3934/agrfood.2020.4.681?view Type $=$ HTML, (last accessed on 11/09/2021), p. 682.

2 Ibid.

3 Ibid.

4 Ibid.

5 Ibid.

6 Djurfeldt, note 1, p. 682.

7 Ibid. 
Youth constitute a majority of the total labour force, yet they are faced with limited access to resources and inputs. ${ }^{8}$ Lack of employment opportunities within agricultural sector is driving the youth away from rural areas. ${ }^{9}$ Currently, there is a strong mismatch between the newly created jobs of 50,000-60,000 yearly and the 900,000 young Tanzanians who yearly enter the labour market. ${ }^{10}$ Only 15 percent of youth in Tanzania have regular salaried jobs with a 12-months contract, while three quarters of the youth engage in farming. ${ }^{11}$

With regard to Agriculture, Tanzania has rich natural resources for agricultural development. The country has 94.5 million hectares of land of which 44 million hectares are classified as arable, but only $24 \%$ of the arable land is under cultivation. Of the 50 million hectares, suitable for livestock, only 26 million hectares are under use while the rest cannot be accessed mainly due to tsetse fly infestation. ${ }^{12}$ The country has the third largest livestock population in Africa after Sudan and Ethiopia. ${ }^{13}$ About 29.4 million hectares of land are assessed as potential for irrigation, of which 2.3 and 4.8 million hectares are regarded as high and medium potential, respectively. ${ }^{14}$

Though the country is well endowed with a high potential base for agriculture development, there is only a small quantity of large-scale commercial farms in the sector. ${ }^{15}$ Agricultural production is dominated by smallholders. ${ }^{16}$ They represent most of the rural families, however notably, half of them are commercial, not subsistence, in that they sell from a minimum of one-quarter of their output to typically half or more in the local community. ${ }^{17}$

The level of farm mechanization is still low that majority of the implements found on farming households on the Mainland are hand hoes $(97.8 \%)$ and swords $(93.5 \%) .{ }^{18}$ Relatively a small number of households use other farming implements such as ox plough $(14.4 \%)$, castrated bulls $(13.7 \%)$, hand sprayers $(11.7 \%)$ and cows $(10.2 \%) .{ }^{19}$ Other farm machinery (tractors, power-tillers) are nearly $1 \%{ }^{20}$ Farm mechanization, especially for

8 Ibid., p. 684.

9 Ibid.

10 Ibid., p. 682.

11 Ibid.

12 The United Republic of Tanzania, Agricultural Sector Development Strategy - II, 2015/2016 2024/2025, p. 5.

13 Ibid.

14 Ibid.

15 Ibid.

16 Ibid.

17 The United Republic of Tanzania, Agricultural Sector Development Strategy, note 12, p. 9.

18 Ibid.

19 Ibid.

20 Ibid. 
land preparation, planting and harvesting, is one of the elements for commercialization of the sector. ${ }^{21}$

Although agriculture is the largest economic sector where more than 75 per cent of the population are engaged, the sector has been experiencing a wide gap in youth's involvement. ${ }^{22}$ Engaging youth in agriculture has been a prominent issue in the past years and has been raised up in the development agenda, as there is growing concern worldwide that young people have become disenchanted with agriculture, to the extent that, youth participation in agriculture has been noted to dwindle every year. ${ }^{23}$

\section{TANZANIA'S AGRICULTURE VISION}

Agriculture in general is viewed as an important contributor to realization of TDV (2025), and so the ASDS II (Agricultural Sector Development Strategy 2015/15-2025/26) envisages an agricultural sector in the year 2025 being modernized, commercial, market-oriented, highly productive and profitable, resilient, utilizing natural resources in an sustainable manner, securing food security throughout the country, expanding its export to regional and international markets and contributing to improved livelihood in rural and urban area of the country. ${ }^{24}$ Only four (4) years remain before 2025 but unfortunately, the sector is still underdeveloped and the youth seem to still be left far behind.

\section{E. EFFORTS TO INCENTIVISE THE YOUTH INTO COMMERCIAL FARMING}

Numerous efforts have been made toboost commercial farming so as to attract the youth and motivate them to actively take part in that activity. Most efforts have been done by the government of the United Republic of Tanzania, but also there are some efforts from private actors. Below are most of the notable ones:-

\section{The Agricultural Inputs Trust Fund (AGITF).}

This is a revolving fund which is under the Management of Board of Trustees. The fund was established by an Act of Parliament No. 9 of $1994 .{ }^{25}$ Its roles include to ensure the availability of funds to finance the procurement and distribution of agricultural inputs; to monitor timely delivery, distribution and storage of agricultural inputs; to maintain and apply the finances of the funds in accordance with sound financial principles; to grant

21 Ibid.

22 The United Republic of Tanzania, Ministry ofAgricultureLivestock and Fisheries, National Strategy for Youth Involvement in Agriculture (NSYIA) 2016-2021, p. 4.

23 Ibid., p. 5.

24 The United Republic of Tanzania, Agricultural Sector Development Strategy, note 12, p. 18.

25 The Agricultural Input Trust Fund Act, Chapter 401 of the laws of the United Republic of Tanzania. 
loans on sound principles and in particular with regards to ensuring timely recovery of the principal sum and any interest payable on any loan; and to cooperate with relevant institutions and authorities responsible for monitoring and enforcing standards or quality of products in order to ensure that agricultural inputs imported on loan from the funds are of acceptable standard or quality. ${ }^{26}$ The public finance from AGITF and TIB-Agricultural window and commercial banks are extending loans for purchase of for tractor, power-tiller, and combine-harvester.$^{27}$ Although the youth are not specifically targeted by the fund, they are among the beneficiaries of that arrangement because the fund is available for all farmers.

\section{Access to other financial resources}

There are in place active SACCOS (Savings and Credit Cooperative Societies) ${ }^{28}$ that provide loans to its members for purchasing agricultural machinery. ${ }^{29}$ Young persons are among those who qualify to create and engage in SACCOS platforms so as to benefit from the loans. Parallel to that, the central government through its ministries has been providing soft loans to the youth for facilitating various economic activities including commercial farming.

During the financial year 2019/2020, the government estimated 1.2 billion shillings to the Prime Minister's Office to implement programs related to youth mobilization, upbringing, and social economic empowerment. ${ }^{30}$ During the 2018/2019 budget implementation, loans amounting to 4.2 billion were provided to 755 youth groups through the National Youth Development Fund (NYDF) compared to 783 million during the financial year 2017/2018 which formed 840 loans. ${ }^{31}$ As of June, 2021, the Youth Development Fund (YDF) that has extended more than Sh5.4 billion benefiting more than 6,293 young people. ${ }^{32}$ Moreover, young people enjoy soft loans under the mandatory provision of loans to the youth from $4 \%$ of the Local Government Authorities (LGAs). ${ }^{33}$ Despite the positive de-

26 The United Republic of Tanzania, Ministry ofAgriculture, Agricultural Inputs Trust Fund, (AGITF), https://www.kilimo.go.tz/index.php/en/stakeholders/view/agricultural-inputs-trust-fund-agitf, (last accessed on 22/09/2021).

27 The United Republic of Tanzania, Agricultural Sector Development Strategy, note 12, pp. 9 -10.

28 SACCOS are established under the Cooperative Societies Act, Chapter 211 of the Laws of the United Republic of Tanzania. The main purpose of such organisations is to encourage thrift among its members and to create a source of credit to its members at a fair and reasonable rate of interest (S. 1 of the Act).

29 The United Republic of Tanzania, Agricultural Sector Development Strategy, note 12, p. 10.

30 Policy Forum, The State of Youth Empowerment and Financial Inclusion in Tanzania, 2021, https://www.policyforum-tz.org/node/5632, (last accessed on 22/09/2021), p. 1.

31 Ibid.

32 The Citizen, Government Outlines Plans towards Addressing Youth Unemployment, https://www.t hecitizen.co.tz/tanzania/news/government-outlines-plans-towards-addressing-youth-unemploymen t-3439138, (last accessed on 12/08/2021).

33 Policy Forum, note 30. 
velopment, the number of young people benefiting from those arrangements is still very small compared to the total population size of the youth in need of financial support.

\section{The Initiative of National Financial Inclusion Framework by MOF}

The framework seeks to ensure that financial products and services meet the needs of individuals and businesses consistent with supporting livelihood improvement, household resilience and creation of jobs. ${ }^{34}$ It recognizes that opening up opportunities for young people to effectively engage in economic activities to earn a living and prosper is fundamental to development. ${ }^{35}$

\section{Tanzania Agricultural Development Bank Limited (TADB)}

The bank was established in 2012 with a mandate to lead capacity-building strategies and programmes to strengthen the agriculture financing value chain and to support the Government of Tanzania initiatives to shape and implement policies and initiatives for agricultural and rural lending.

\section{The National Agriculture Policy}

The policy's mission is to facilitate the transformation of the agricultural sector into modern, commercial and competitive sector in order to ensure food security and poverty alleviation through increased volumes of competitive crop products. ${ }^{36}$

\section{National Strategy for Youth Involvement in Agriculture (NSYIA) 2016-2021}

The mission of the strategy is to facilitate and build the capacity of the youth for self-employment in agriculture. ${ }^{37}$ The overall objective of that initiative is to provide a strategic framework that will promote and facilitate the coordinated implementation of interventions regarding youth involvement in agriculture. ${ }^{38}$

34 The United Republic of Tanzania, National Financial Inclusion Council, National Financial Inclusion Framework, 2018 - 2022, https://www.fsdt.or.tz/wp-content/uploads/2019/01/National-Finan cial-Inclusion-Framework-NFIF-2018-2022.pdf, (last accessed on 18/08/2021), p. 7.

35 Ibid.

36 The United Republic of Tanzania, Ministry of Agriculture, Food Security and Cooperatives, The National Agriculture Policy, 2013, p. 9.

37 The United Republic of Tanzania, Ministry of Agriculture Livestock and Fisheries, note 22, p. 15.

38 Ibid, p. 16. 


\section{The Tanzania Youth Development Policy.}

The mission of that policy is to create an enabling environment for youth empowerment and enhancement of employment opportunities and security. ${ }^{39}$ In the said policy, the youth are highlighted as the driving force behind social economic and political reforms in the sphere of rapid global changes ${ }^{40}$ hence they play a central role in the national socio-economic development and need to be included in planning and building the future. ${ }^{41}$ The policy, furthermore, recognizes that youth in Tanzania are a vulnerable group due to an insufficient labour market and the surrounding negative perceptions of youth regarding farming and agriculture. ${ }^{42}$ Meanwhile, the agricultural sector (including production and agro-industries) is identified as one potential area for employment creation. ${ }^{43}$

\section{The Youth Development Fund}

The Youth Development Fund (YDF) had a big emphasis on employment creation. ${ }^{44}$ Phase One of the YDF was established in 1993/94 and the Phase Two was launched in 2000.45 The funds were popularly known as the Jakaya Kikwete (JK) Funds since they were initiated by the President. ${ }^{46}$ Other objectives of the Fund included to avail credit to adults and youth with business ideas and projects; and to promote the culture of banking and savings. ${ }^{47}$ The provision of funds by the YDF for setting up enterprises has been directed to groups and not to individuals. ${ }^{48}$ YDF has been implemented directly with the SACCOS through the District Administration Account from where the funds are disbursed to the SACCOS, who then lend to their members. ${ }^{49}$

39 The United Republic of Tanzania, Ministry of Labour, Employment and Youth Development, National Youth Development Policy, 2007, p. 9.

40 Ibid., p. 1.

41 Ibid.

42 Djurfeldt, note 1, p. 683.

43 The United Republic of Tanzania, Ministry of Labour, Employment and Youth Development, note 39 , p. 3.

44 International Labour Organization, Key Questions on National Youth Funds (NYF), Supporting Youth to Create Sustainable Employment Opportunities, 2012, https://www.ilo.org/wcmsp5/group s/public/---ed_emp/documents/project/wcms_206200.pdf, (last accessed on 28/11/2021), p. 3.

45 Ibid., p. 6.

46 Ibid., p. 3.

47 Ibid.

48 Ibid., p. 8.

49 Ibid. 


\section{Tax Incentives}

The Government' efforts for promoting mechanization in agriculture include tax exemption for importation of farm machinery and spare parts. ${ }^{50}$ Another notable development is the produce cess reform. Prior to 2017, there was strong criticism against the price cess tax was strongly criticised for reducing the incentive to the farm to produce and trade, affecting farm profitability, reducing the competitiveness of Tanzanian agriculture abroad, creating market distortion, as the level of taxation was not equal between LGAs (creating tax avoidance strategy), worsening food security and poverty level; and creating uncertainty over the final producer price if there is lack of clarity on the eligibility of the products (example whether crops produced for seeds might be subject to the tax)..$^{51}$

Due to stakeholder pressure, the government in 2017 amended the Local Government Finance Act by reducing the cap of the cess rate from $5 \%$ to $3 \%{ }^{52}$ Thereafter, efforts have been underway to go further by decreasing the cess rate even more in 2020 , to continue reducing disparities in current rates across both crops and LGAs. ${ }^{53}$ Several options are currently under discussion namely either total removal of the produce cess, or a uniform cess rate reduction for all crops and all LGAs, or a differential cess rates by crop types (food vs non-food crops). ${ }^{54}$ The incentives are applicable to anyone in general, which includes the youth.

Despite those positive developments, it has been suggested that a uniform cess rate of $1 \%$ for both staple and cash crops ( $1 \%$ cess scenario) is the most efficient policy option, as it has the highest cost-benefit ratio. ${ }^{55}$ However, that rate has not yet been achieved because further reforms have not taken place.

\section{F. WHERE THE PROBLEM LIES}

Evidently, the government and other stakeholders are taking action to make commercial farming accessible by the young generation. However, it is apparent that all those efforts do not seem to fully bear the desired fruits. The general trend in the past 13 years shows that there has been a rise of micro and small-scale businesses in rural areas which in one way or the other motivated many youths to leave farming; engaging instead in other activities, including petty trade, motorbike transport business commonly known as bodaboda, food

50 The United Republic of Tanzania, Ministry of Labour, Employment and Youth Development, note 39 , p. 9.

51 Aymeric Ricome, Kamel Louhichi, Sergio Gomez-y-Paloma, Impacts of Agricultural Produce Cess (Tax) Reform Options in Tanzania, 2020, https://publications.jrc.ec.europa.eu/repository/bitstream /JRC116791/jrc116791_producecessimpact_online_1.pdf, doi:10.2760/560972, (last accessed on 02/09/2021), p. 16.

52 Ricome, note 51, p. 16.

53 Ibid.

54 Ibid.

55 Ibid., p. 43. 
vending, and agricultural related businesses. ${ }^{56}$ Most youth do not take agriculture as a profession and are, therefore, likely to be attracted by other emerging opportunities other than farming. ${ }^{57}$

In other situations, due to the responsibility of running the family at a young age for some, youth take it necessary to engage themselves in the activities that provide daily income rather than agriculture which is seasonal and unpredictable. ${ }^{58}$ Thus, the need of quicker money necessitates youth headed households to engage more in non-farming activities. ${ }^{59}$ Based on this trend, it is likely that in the near future farming will be left in the hands of the elderly population. ${ }^{60}$

The problem is also present among those who have been lucky to attain some level of education. Youths with higher levels of education take farming as a tiresome job and thus consider formal employment to be more secure, with predictable flow of income than farming. ${ }^{61}$ It can be argued that agriculture in general is negatively perceived by the young generation irrespective of one's socio-economic status, and that negative perception automatically extends to commercial farming. The following are some of the major reasons for the low rate of youth involvement in commercial farming:-

\section{Availability of financial resources.}

Despite all the efforts highlighted above, the funding to the youth development programmes in general remains far low. ${ }^{62}$ Inadequate financial service for small commercial farmers is a major constraint to agricultural growth. ${ }^{63}$ Majority of youth in Tanzania still lack financial capacity to invest in agriculture. ${ }^{64}$ They are not eligible for loans/credit from financial institutions as they lack collateral. ${ }^{65}$ Despite the Government emphasis on commercial agriculture, access to financing amongst youth for agricultural investments is still limited. ${ }^{66}$ This has led to failure in provision of business licenses by relevant authorities for agricul-

56 Nelson Albert Ochieng, Are Youth Moving towards or away from Agriculture? Analysis of Farm and Non-farm Occupational Choices among Youth in Rural Tanzania, 2021, chrome-extension://ef aidnbmnnnibpcajpcglclefindmkaj/viewer.html?pdfurl=https $\% 3 \mathrm{~A} \% 2 \mathrm{~F} \% 2 \mathrm{Fwww}$. repoa.or.tz $\% 2 \mathrm{Fwp}$ -content $\% 2$ Fuploads $\% 2 F 2021 \% 2 F 02 \% 2 F Y$ outh-Occupational-Choice-1.pdf\&clen=768039\&chun $\mathrm{k}=$ true, (last accessed on 20/09/2021), p. 13.

57 Ibid., p. 14.

58 Ochieng, note 56, p. 14.

59 Ibid.

60 Ibid., p. 23.

61 Ibid.

62 Policy Forum, note 30.

63 The United Republic of Tanzania, Agricultural Sector Development Strategy, note 12, p. 31.

64 The United Republic of Tanzania, Ministry ofAgriculture Livestock and Fisheries, note 22, p. 17.

65 Ibid.

66 Ibid. 
tural projects and also failure of TRA to issue TIN for agricultural projects/activities, hence limiting youth acquisition of loans from financial institutions. ${ }^{67}$ Youths are regarded as a risky group to offer credit, hence many of them do not qualify for loans. ${ }^{68}$ Moreover, rural land, which could have served as collateral, is neither recognized nor accepted by some of the financial institutions. ${ }^{69}$ Consequently, youths have been hesitant to engage in agricultural production which in most cases requires substantial capital if one is to adopt modern agriculture. ${ }^{70}$

One plausible alternative would be to secure loans through groups, however, majority of youths are not in formal registered groups. ${ }^{71}$ This is either because they are not sensitized or are unaware of the conditions of eligibility for loan accessibility. ${ }^{72}$ Another reason is fear of high interest and transaction rates accompanying the loans. ${ }^{73}$

Furthermore, evidence on ground has revealed that accessibility of the available funds through LGAs remains challenging due to the compelling need to target the youth who can demonstrate the recoverability of the funds. ${ }^{74}$ Owing to this, it has been common that those who have well established businesses (rather than the neediest) are more likely to access the loans. ${ }^{75}$

There is also a revealed trend of low disbursement of the funds across councils. ${ }^{76}$ For instance 61.6 billion was allocated to 18,233 groups (both women and youth), but only 15.6 billion were disbursed to 8,672 groups during the 2017/2018 financial year. ${ }^{77}$ An audit report for the 2016/17 period by the Controller and Auditor General (CAG) revealed that Sh 53.223 billion was not contributed by 143 Local Government Authorities (LGAs) to the Women and Youth Development Fund (WYDF). ${ }^{78}$

67 Ibid.

68 Landesa Tanzania, Youth Land Rights in Tanzania: Challenges, Opportunities and Policy Options, 2021, chrome-extension://efaidnbmnnnibpcajpcglclefindmkaj/viewer.html?pdfurl=https $\% 3 \mathrm{~A} \% 2 \mathrm{~F}$ $\% 2$ Fwww.landesa.org\%2Fwp-content $\% 2$ Fuploads $\% 2$ Ffinal-version-Tanzania-Youth-Land-Policy -Brief.pdf\&clen=1433592\&chunk=true, (last accessed on 05/09/2021), p. 6.

69 The United Republic of Tanzania, Ministry ofAgricultureLivestock and Fisheries, note 22, p. 17.

70 Ibid.

71 Ibid., pp. $17-18$.

72 Ibid., p. 18.

73 Ibid.

74 Policy Forum, note 30.

75 Ibid.

76 Ibid.

77 Ibid.

78 The Citizen,LGAs Failed to Provide Sh53bn in Youth Fund,2018, https://www.thecitizen.co.tz/tanz ania/news/lgas-failed-to-provide-sh53bn-in-youth-fund-2635298, (last accessed on 12/09/2021). 
Many young people rely on and friends for borrowing, or on their own savings for starting, operating or expanding a farm. ${ }^{79}$

\section{Lack of access to land.}

The issue of land is very problematic in Tanzania. Land is a key resource to achieve economic empowerment, however youth have limited access to land as well as capital to purchase it. ${ }^{80}$ Girls are especially vulnerable in this regard since customary practice excludes them from inheritance and land ownership. ${ }^{81}$ Population growth, delays transfers of land between generations as parents live longer and need to keep their land. The increase of medium-scale commercial farms is the major factors that hinder access to land by the youth. ${ }^{82}$ Consequently, youth to a larger extent work on family land or, if they have the financial resources, rent land. ${ }^{83}$

Most rural youth in Tanzania gain access to land through inheritance, as in other parts of sub-Saharan Africa. ${ }^{84}$ It takes long for the inheritance to be accessible and chances of getting enough land for commercial agriculture are usually low because of either a big number of heirs or a small size of the land to be inherited. Moreover, Inheritance is normally governed by customary norms and practices that discriminate against youth especially girls who face discrimination and are placed at the third tier of inheritance. ${ }^{85}$

\section{Legal and regulatory framework.}

The legal and regulatory framework often represents a key challenge to delivering financial services to youth. ${ }^{86}$ Such challenges include cumbersome procedures of opening a bank account, obtaining land rights, obtaining a loan et cetera. Weak property rights and even total lack of access to production factors (such as water and land) make collateral requirements

79 OECD, Advancing the Digital Financial Inclusion of Youth, 2020, chrome-extension://efaidnbmnn nibpcajpcglclefindmkaj/viewer.html?pdfurl=https $\% 3 \mathrm{~A} \% 2 \mathrm{~F} \% 2 \mathrm{Fwww}$. oecd.org $\% 2 \mathrm{Fdaf} \% 2 \mathrm{Ffin} \% 2$ Ffinancial-education $\% 2$ Fadvancing-the-digital-financial-inclusion-of-youth.pdf\&clen $=2655181 \& \mathrm{c}$ hunk=true, (last accessed on 13/09/2021), p. 37.

80 Djurfeldt, note 1, p. 683.

81 The United Republic of Tanzania, Ministry of Labour, Employment and Youth Development, note 39, p. 11.

82 Djurfeldt, note 1, p. 693.

83 Ibid.

84 Landesa, note 68, p. 5.

85 Ibid., pp. 5 -6.

86 Arianna Gasparri Laura Munoz, Inclusive Finance and Rural Youth, Papers of the 2019 Rural Development Report, 2019, https://www.ifad.org/documents/38714170/41187395/11_Gasparri+a nd+Munoz_2019+RDR+BACKGROUND+PAPER.pdf/1446b159-ed1b-5ae9-fb1f-c0af77e698c8, (last accessed on 13/09/2021), p. 18. 
hard to meet. ${ }^{87}$ Mohammed and Wei emphasize that regulatory requirements such as know your customers rules that have been introduced to prevent money laundering can also make it difficult for poor people to open even a bank account as they may not have the necessary documentation. ${ }^{88}$

\section{Lack of financial education}

The sustainability of the soft loans-for-youth approach is threatened by, among other, lack of strong entrepreneurship and financial management skills among the youth. ${ }^{89}$ Consequently, many youth are regarded as not having adequate financial discipline and they are viewed as a highly risky group.

\section{Low prices of products}

Fetching good market prices of the agricultural product, id est, farm gate prices, is crucial for the smallholders. ${ }^{90}$ However, most of the agricultural products fetch low market prices due to low quality resulting from low adoption of improved technology including improved variety, nutrients (fertilizer), pest management, and under recognition of market requirements. ${ }^{91}$ Limited amount of production mainly due to low productivity and limited cultivated area also significantly affects the farm gate prices offered by middle-men at the farm gate. ${ }^{92}$ Weak mechanism for accreditation, testing, quality monitoring, grades and standards of agricultural products also affects the price determination. ${ }^{93}$

Clearly, the beautifully drafted strategies, policies, legal provisions and rhetoric have not yet been able to intensify youth engagement in commercial farming. The young men and women are still lagging far behind, and in some cases even moving away from farming, hence there is a need for better strategies. More youth-centred legal incentives are among the strategies which will most likely address the situation.

87 Ibid., p. 9.

88 Mohammed Salim Ahmed, and Wei Jianguo, Financial Inclusion and Challenges in Tanzania, Research Journal of Finance and Accounting, vol. 5, 2014, chrome-extension://efaidnbmnnnibpcaj pcglclefindmkaj/viewer.html?pdfurl=https $\% 3 \mathrm{~A} \% 2 \mathrm{~F} \% 2 \mathrm{Fcore} . \mathrm{ac} . \mathrm{uk} \% 2 \mathrm{Fdownload} \% 2 \mathrm{Fpdf} \% 2 \mathrm{~F} 234$ 630228.pdf\&clen=293181\&chunk=true, (last accessed on 02/08/2021), p. 6.

89 Policy Forum, note 30.

90 The United Republic of Tanzania, Agricultural Sector Development Strategy, note 12, p. 5.

91 Ibid.

92 Ibid.

93 Ibid. 


\section{G. THE REQUIRED LEGAL INCENTIVES}

A legal incentive is a set of legal norms that establish certain means of influencing the mind and psyche of a person in order to strengthen their motivation for lawful behavior. ${ }^{94}$ Creation and implementation of appropriate legal incentives will positively influence the youth and thereby motivate them to actively engage in commercial farming. The following are the requisite incentives:

\section{Financial incentives}

The youth need availability of more and easily accessible financial support. All studies of agricultural finance show that ease of access to agricultural finance is the number one requirement of small commercial farmers. ${ }^{95}$ That can be achieved through promoting agricultural lending from commercial banks, ${ }^{96}$ and establishing stronger and well capitalized grassroots-level micro-finance institutions such as SACCOS and Village Community Banks (VICOBA) as first-line of financial service for small commercial farmers. ${ }^{97}$ The existing number of such institutions in too small compared to the number of young persons in need of the support.

Moreover, the government, through its agencies and in collaboration with the private sector, should develop a pro-youth and pro-rural credit and finance facility to underwrite the costs of youth accessing land through formal processes. ${ }^{98}$

Micro credit institutions have been successful at operating the large number of branches required, however, their loans are small compared to the needs of small commercial farmers. ${ }^{99}$ They may lend to the lower size limit of the small commercial farmers, example, farms of one to one and half hectares, but rarely larger than that. ${ }^{100}$ More importantly, the means of ensuring high repayment rates, intimate organization of small numbers of relatively homogenous participants, tied to savings of a size comparable to the loans and group guarantees work less well with the small commercial farmers and the much larger size loans. ${ }^{101}$

94 Aleksandr Gavritskiy, Svetlana Miroshnik, 2018, Discussion on Issues of the Theory of Legal Incentives, 2018, https://ojs.journals.cz/index.php/CBUIC/article/view/1214, (last accessed on 05/08/2021).

95 The United Republic of Tanzania, Agricultural Sector Development Strategy, note 12, p. 49.

96 Ibid., p. 31.

97 Ibid.

98 Landesa, note 68, p. 8.

99 The United Republic of Tanzania, Agricultural Sector Development Strategy, note 12, p. 49.

100 Ibid.

101 The United Republic of Tanzania, Agricultural Sector Development Strategy, note 12, p. 49. 
Youth need to be able to take loans to invest in agriculture (land and inputs). ${ }^{102}$ Aside from private sources of finance, governments are also important sources of finance for developing country agriculture. ${ }^{103}$ There is a need for establishing other promising government initiatives such as the creation of more financial institutions in agriculture, whose regulations are usually defined by central banks. ${ }^{104}$

The Government should also explore opportunities to partner with banks to facilitate access to land, finance, and entrepreneurship skills for youth to encourage investment in their land and reduce risks associated with loan repayment. ${ }^{105}$ In general, enabling legal and regulatory frameworks promote the increase of financial access points and widen outreach of financial services to the excluded population ${ }^{106}$ which includes the young generation.

In June this year, the current President Her Excellency Samia Suluhu Hassan announced plans to establish a commercial bank that will specifically come up with tailormade services that target young entrepreneurs. ${ }^{107}$ The President added that the establishment of this bank would help in addressing access to capital challenge that is facing the youth in the country. ${ }^{108}$ This will be a commendable incentive if it will be managed well and properly respond to the needs of the youth. Establishment of banks and branches with similar missions close to rural areas where most of the youth population is will be very crucial.

\section{Improving access to land by the young generation as collateral or for agriculture}

The government should develop suitable land reforms that will recognize youth and allocate land for youth agricultural projects in urban and rural areas. ${ }^{109}$ Successful land reforms necessitate awareness raising and creation, to local and national level government authorities mandated with land allocation, youth and youth groups, and other youth actors including CSOs to enhance their understanding of youth land rights, the importance of youth access to land, unique needs for youth and the potential opportunity youth present on transforming the country's economy. ${ }^{110}$ Similarly, equitable access to land needs to be pro-

102 Djurfeldt, note 1, p. 696.

103 Marina Ruete, Financing for Agriculture: How to Boost Opportunities in Developing Countries, 2015, https:/www.iisd.org/system/files/publications/financing-agriculture-boost-opportunities-de vloping-countries.pdf, (last accessed on 06/08/2021), p. 14.

104 Ruete, note 103, p. 7.

105 Landesa, note 68, p. 9.

106 The United Republic of Tanzania, National Financial Inclusion Council, note 34, p. 3.

107 The Citizen, Government Outlines Plans towards Addressing Youth Unemployment, note 32.

108 Ibid.

109 Landesa, note 68, p. 7.

110 Ibid. 
moted through binding legal provisions, and rural youth and gender should be emphasised in this regard. ${ }^{111}$

\section{More education to the youth}

Youth need to be targeted in training programs, which could help them in commercializing farming. ${ }^{112}$ In general, financial education among the youth should be promoted ${ }^{113}$ because financial literacy is an essential skill for young people. Introducing and sustaining high quality financial education initiatives at critical transition moments for young people is of paramount importance. Financial education provision should not be sporadic, should be based on evidence, and be focused on the youth that are most in need. ${ }^{114}$ Including financial education in the school curriculum is recognised as one of the most efficient and fair ways to reach a whole generation on a broad scale. ${ }^{115}$ Parallel to that, youth in rural areas should interact with successful farmers as their role models. ${ }^{116}$ The fact that many young people are exposed to hard labour from their childhood, while depending on their parents as the main source of information about farming gives agriculture a negative image. ${ }^{117}$ May be the young people see the activity as an ugly culture and not agriculture. To address that problem, youth with development ambitions, should source their mentorship from successful farmers which will help change their negative attitude towards farming. ${ }^{118}$ Also, strategically designed and implemented programmes for change of perception are much needed because the negativity against agriculture is deep rooted in the minds of the youth. For this strategy to work effectively, it should be encapsulated in a relevant legal framework.

\section{Stabilising markets}

Stabilizing markets for agricultural products in rural areas is of great significance. ${ }^{119}$ Stable markets guarantee farming income flow which is the reason why most of youth exposed to education prefer participating in non-farming activities. ${ }^{120}$ Regulatory authorities have the opportunity to design rules that will make markets stable and therefore attractive to the young generation.

111 Djurfeldt, note 1, p. 683

112 Ibid., p. 696.

113 Gasparri, note 86, pp. $18-19$

114 OECD, p. 58, note 79.

115 Ibid.

116 Ibid.

117 Ibid.

118 Ochieng, note 56, p. 24.

119 Ochieng, note 56, p. 24.

120 Ibid. 


\section{More tax incentives}

Produce cess reduction to $1 \%$ in both cash and food crops is necessary so as to reduce the tax burden and enable commercial farmers to realise more profits. In addition, more youthcentric tax incentives should be introduced in order to specifically respond to the particular challenges facing that group.

\section{H. CONCLUSION}

A lot of work needs to be done in incentivising the young generation into engaging in commercial farming. The government and other stakeholders should make purposive efforts to translate into reality all the existing aspirations for intensifying engagement of young people in commercial farming. Moreover, for the legal incentives to work, they should be specifically directed towards the youth and the youth should be assisted to build a positive attitude towards commercial farming. Furthermore, the fruits of those incentives will be realised if the youth change their negative perception against farming.

\section{BIBLIOGRAPHY}

The Agricultural Input Trust Fund Act, Chapter 401 of the laws of the United Republic of Tanzania The Cooperative Societies Act, Chapter 211 of the Laws of the United Republic of Tanzania.

Agnes Andersson Djurfeldt, Aida Cuthbert Isinika, ElibarikiMsuya and Karin Lindsjö, Youths' Participation in Agricultural Intensification in Tanzania, AIMS Agriculture and Food, volume 5, 2020, p. 682, available athttps://www.aimspress.com/article/doi/10.3934/agrfood.2020.4.681?viewType=H TML, (last accessed on 11/09/2021)

Aleksandr Gavritskiy, Svetlana Miroshnik, 2018, Discussion on Issues of the Theory of Legal Incentives, 2018, https://ojs.journals.cz/index.php/CBUIC/article/view/1214, (last accessed on 05/08/2021).

Arianna Gasparri Laura Munoz, Inclusive Finance and Rural Youth, Papers of the 2019 Rural Development Report, 2019, https://www.ifad.org/documents/38714170/41187395/11_Gasparri+and+M unoz 2019+RDR+BACKGROUND+PAPER.pdf/1446b159-ed1b-5ae9-fb1f-c0af77e698c8, (last accessed on 13/09/2021), p. 18.

Aymeric Ricome, Kamel Louhichi, Sergio Gomez-y-Paloma, Impacts of Agricultural Produce Cess (Tax) Reform Options in Tanzania, 2020, https://publications.jrc.ec.europa.eu/repository/bitstream /JRC116791/jrc116791_producecessimpact_online_1.pdf, doi:10.2760/560972, (last accessed on 02/09/2021)

International Labour Organization, Key Questions on National Youth Funds (NYF), Supporting Youth to Create Sustainable Employment Opportunities, 2012, https://www.ilo.org/wcmsp5/groups/publi c/---ed_emp/documents/project/wcms_206200.pdf, (last accessed on 28/11/2021). 
Landesa Tanzania, Youth Land Rights in Tanzania: Challenges, Opportunities and Policy Options, 2021, chrome-extension://efaidnbmnnnibpcajpcglclefindmkaj/viewer.html?pdfurl=https\%3A\%2F $\% 2$ Fwww.landesa.org\%2Fwp-content\%2Fuploads\%2Ffinal-version-Tanzania-Youth-Land-Policy -Brief.pdf\&clen=1433592\&chunk=true, (last accessed on 05/09/2021)

Marina Ruete, Financing for Agriculture: How to Boost Opportunities in Developing Countries, 2015, https://www.iisd.org/system/files/publications/financing-agriculture-boost-opportunities-devloping -countries.pdf, (last accessed on 06/08/2021).

Mohammed Salim Ahmed, and Wei Jianguo, Financial Inclusion and Challenges in Tanzania, Research Journal of Finance and Accounting, vol. 5, 2014, chrome-extension://efaidnbmnnnibpcajpcglclefin dmkaj/viewer.html?pdfurl=https\%3A\%2F\%2Fcore.ac.uk\%2Fdownload\%2Fpdf\%2F234630228.pd $\mathrm{f} \& \mathrm{clen}=293181 \&$ chunk $=$ true, (last accessed on 02/08/2021), p. 6.

Nelson Albert Ochieng, Are Youth Moving towards or away from Agriculture? Analysis of Farm and Non-farm Occupational Choices among Youth in Rural Tanzania, 2021, chrome-extension://efaidn bmnnnibpcajpcglclefindmkaj/viewer.html?pdfurl=https $\% 3 \mathrm{~A} \% 2 \mathrm{~F} \% 2 \mathrm{Fwww}$.repoa.or.tz\%2Fwp-con tent $\% 2$ Fuploads\%2F2021\%2F02\%2FYouth-Occupational-Choice-1.pdf \&clen=768039\&chunk=tr ue, (last accessed on 20/09/2021).

OECD, Advancing the Digital Financial Inclusion of Youth, 2020, chrome-extension://efaidnbmnnnibp cajpcglclefindmkaj/viewer.html?pdfurl=https $\% 3 \mathrm{~A} \% 2 \mathrm{~F} \% 2 \mathrm{Fwww}$.oecd.org $\% 2 \mathrm{Fdaf} \% 2 \mathrm{Ffin} \% 2 \mathrm{Ffina}$ ncial-education $\% 2$ Fadvancing-the-digital-financial-inclusion-of-youth.pdf \&clen=2655181\&chunk $=$ true, (last accessed on 13/09/2021).

Policy Forum, The State of Youth Empowerment and Financial Inclusion in Tanzania, 2021, https://ww w.policyforum-tz.org/node/5632, (last accessed on 22/09/2021)

The Citizen, Government Outlines Plans towards Addressing Youth Unemployment, https://www.thecit izen.co.tz/tanzania/news/government-outlines-plans-towards-addressing-youth-unemployment-343 9138, (last accessed on 12/08/2021)

The Citizen, LGAs Failed to Provide Sh53bn in Youth Fund, 2018, https://www.thecitizen.co.tz/tanzani a/news/lgas-failed-to-provide-sh53bn-in-youth-fund-2635298, (last accessed on 12/09/2021).

The United Republic of Tanzania, Agricultural Sector Development Strategy - II, 2015/2016 2024/2025

The United Republic of Tanzania, Ministry ofAgriculture, Agricultural Inputs Trust Fund, (AGITF), https://www.kilimo.go.tz/index.php/en/stakeholders/view/agricultural-inputs-trust-fund-agitf (last accessed on 22/09/2021)

The United Republic of Tanzania, Ministry of Agriculture, Food Security and Cooperatives, The National Agriculture Policy, 2013

The United Republic of Tanzania, Ministry ofAgricultureLivestock and Fisheries, National Strategy for Youth Involvement in Agriculture (NSYIA) 2016-2021

The United Republic of Tanzania, Ministry of Labour, Employment and Youth Development, National Youth Development Policy, 2007

The United Republic of Tanzania, National Financial Inclusion Council, National Financial Inclusion Framework, 2018 - 2022, https://www.fsdt.or.tz/wp-content/uploads/2019/01/National-Financial-I nclusion-Framework-NFIF-2018-2022.pdf, (last accessed on 18/08/2021) 